\title{
GAMBARAN PENANAMAN NILAI-NILAI ANTIKORUPSI DI SEKOLAH DASAR ISLAM SUNAN AMPEL II SIDOARJO
}

\author{
Aqidatul Izza ${ }^{1}$, Mustofa ${ }^{2}$ \\ ${ }^{1}$ Universitas Nahdlatul Ulama Surabaya \\ aizza9930@gmail.com \\ ${ }^{2}$ Universitas Nahdlatul Ulama Surabaya \\ Mustofa@unusa.ac.id
}

\begin{abstract}
Abstrak
Pendidikan antikorupsi adalah usaha yang diterapkan di suatu lembaga pendidikan untuk membentuk mental atau karakter siswa antikorupsi. Penelitian ini bertujuan untuk menggambarkan penanaman nilai-nilai antikorupsi di Sekolah DasarIslam Sunan Ampel II Sidoarjo.Penelitian ini bersifat empris dengan pendekatankualitatif deskriptif. Teknik pengambilan data dengan observasi, wawancara, dan dokumentasi. Kegiatan wawancara dilakukan dengan 3 narasumber yakni kepala sekolah dan 2 guru. Sedangkan pelaksanaan observasi dilakukan peneliti selama 4 hari.Hasil penelitian menunjukkan bahwa Sekolah Dasar Islam Sunan Ampel II Sidoarjo telah menerapkan nilai-nilai anti korupsi yang ditunjukkan dengan penerapan 9 (Sembilan) nilai anti korupsi yaitu kejujuran, kemandirian, keberanian, keadilan, kesederhanaan, kepedulian, kerja keras, tanggungjawab, dan kedisiplinan..
\end{abstract}

Kata Kunci: Nilai; Pendidikan; Antikorupsi

\begin{abstract}
Anti-corruption education is an effort applied in an educational institution to build the mental or character of anti-corruption students. This research aims to describe the implementation of anti-corruption values at SDI (Islamic Elementary school) Sunan Ampel II Sidoarjo.This research is empirical one with a descriptive qualitative approach. Data are collected by observation, interviews, and documentation techniques. The interview activities are conducted with 3 (three) speakers, namely the principal and 2 (two) teachers, while the observations are carried out for 4 (four) days.The result of the study indicates that SDI Sunan Ampel II Sidoarjo has already carried out anti-corruption values that could be seen from the implementation of 9 (nine)anti-corruption values such as honesty, independence, courage, justice, simplicity, caring, hard work, responsibility, and discipline.
\end{abstract}

Keywords: Value; Education; Anti-Corruption

\section{PENDAHULUAN}

Korupsi ada sejak manusia pertama kali mengenal tata kelola administrasi. Pada kebanyakan kasus korupsi yang dipublikasikan media, perbuatan korupsi tidak lepas dari kekuasaan, birokrasi, ataupun pemerintahan. Harrison memberikan pernyataan bahwa korupsi mengaburkan penggunaan agenda politik untuk memajukan kepentingan golongan 
atau kekuatan tertentu. Berangkat dari pernyataan tersebut korupsi juga sering dikaitkan dengan pelaksanaan sistem pemerintahan. Selain mengaitkan korupsi dengan pemerintahan, korupsi juga terkait dengan bidang kehidupan bangsa yang lain seperti hukum, ekonomi, sosial budaya, kebijakan publik, kebijakan internasional, kesejahteraan sosial, dan pembangunan nasional (Harrison, 2007:672).

Isu kontemporer dunia merupakan 'penyakit' yang sulit ditemukan 'dianogsa' nya, dikarenakan setiap negara memiliki definisi dan tingkat korupsi yang berbeda-beda. Diperkuat dengan pendapat dari Gebeye yang menyatakan bahwa;

"Corruption is a global phenomenon which every society faces though its degree of severity varies from country to country. Despite its long history, there is no single universally agreed upon definition of corruption. Moreover, its causes, forms and impacts are diverse and multi faceted. Understanding corruption by itself is a complex undertaking. However, it is agreed that corruption is inimical to public administration, undermines democracy, degrades the moral fabrics of the society and violates human rights"'(Gabeye,2012).

Upaya yang sistematik untuk memberantas korupsi harus dilakukan oleh semua pihak baik pemerintah, masyarakat, serta organisasi kemasyarakatan. Sebagaimana hal tersebut telah dilakukan oleh Lithuania melalui sistem integrasi nasional dengan cara mengintegrasikan pilar-pilar publik yaitu kesadaran publik, pengembangan strategi masyarakat antikorupsi, pengawasan lembaga-lembaga peradilan, media, sektor swasta, serta perusahaan internasional. Pilar-pilar publik ini memiliki hubungan saling timbal balik untuk membangun dan memperkuat sistem yang berintegritas dalam memerangi korupsi (Public Administration Quarterly," 274-75, accessed July 12, 2019).

Sejalan dengan upaya pemberantasan korupsi yang dilakukan Lithuania, Hongkong juga melakukan upaya serupa. Hal ini dipaparkan oleh Manion sebagai berikut;

"To realize anti-corruption success, the ICAC developed a three pronged strategy, reflected in its internal structure. The Operations Departement carries out enforcement to discover and investigate corruption and prosecute the corrupt. The Comunity Relations Departement implemtens education to inform the public of the role of the ICAC, spreand knowledge of anti-corruption laws, mobilize the public to report corruption, and raise the moral cost of corrupt actions. The corruption prevention departement work on institutional design to reduce opportunities for corruption"(Manion,2019:82).

Untuk merealisasikan upaya pemberantasan korupsi di Hongkong, dilakukan dengan mengordinasikan semua elemen dari lembaga pemberantasan korupsi di Hongkong.Lembaga-lembaga ini dapat bergerak melalui lembaga penindakan, lembaga pendidikan serta pencegahan. 
Korupsi merupakan masalah besar yang selalu menjadi prioritas negara untuk mengatasinya. Pasalnya, dampak korupsi menjadi sebab utama terpuruknya kondisi suatu negara karena dapat mengganggu sistem pemerintahan, sistem hukum, perekonomian, politik, menghambat pembangunan, merusak moral bangsa menurunkan kepercayaan masyarakat dan dunia internasional (Sujono, 187:13). Upaya pemberantasan korupsi telah dilaksanakan dengan berbagai tindakan secara represif mengingat ia merupakan extraordinary crime yang menghancurkan suatu bangsa dan negara. Ironisnya, tindakan korupsi seolah-olah masih menjadi bagian dari kehidupan bangsa yang ada di berbagai tempat dan dianggap sebagai suatu yang biasa terjadi (Wibowo, 2012:17).

Nampaknya, upaya pemberantasan korupsi melalui tindakan penegakan hukum (represif) belum cukup untuk memberikan solusi atas masalah korupsi yang telah berada di berbagai lapisan di negara ini. Hal ini terbukti dengan rilis dari Transparency Internasional tahun 2016, menempatkan Indonesia pada posisi ke-90 dengan Indeks Persepsi Korupsi (IPK) 36, mengalami peningkatan dari tahun 2017 dengan IPK 37 dengan urutan ke-96. Kendati skor IPK Indonesia mengalami peningkatan, Indonesia masih dalam taraf negara dengan indeks korupsi terbesar di dunia. Oleh karena itu, upaya pemberantasan haruslah diiringi dengan melakukan tindakan preventif dengan membangun filosofi baru berupa penyampaian nilai-nilai anti korupsi melalui pendidikan formal. Hal itu dilakukan karena pendidikan dianggap sebagai alternatif secara preventif untuk membentuk generasi baru yang lebih baik (Sujono, 17).

Keterlibatan pendidikan formal dalam upaya pencegahan korupsi memiliki kedudukan strategis dan antisipatif. Upaya pencegahan korupsi di masyarakat terlebih dahulu dapat dilakukan dengan mencegah berkembangnya mental korupsi pada anak bangsa melalui pendidikan (Gurning, 2013:95). Urgensi penanaman nilai-nilai antikorupsi dalam sistem pendidikan nasional memang harus ditindak lanjuti dengan serius, sedini mungkin melakukan upaya pencegahan berkembangnya korupsi.

Pendidikan antikorupsi secara umum memiliki tujuan sebagai berikut: (1) pembenahan informasi untuk pembentukan pengetahuan dan pemahaman mengenai berbagai bentuk korupsi dan aspek-aseknya, (2) pengubahan persepsi dan sikap terhadap korupsi, (3) pembentukan keterampilan dan kecakapan baru yang dibutuhkan untuk melawan korupsi (Kesuma, 2009:59). Hal tersebut sesuai dengan rumusan nilai-nilai pendidikan antikorupsi yang dikemukan oleh Agus Wibowo meliputi kejujuran, kepedulian, kemandirian, kedisiplinan, tanggung jawab, kerja keras, kesederhanaan, keberanian, serta keadilan (Wibowo, 2013:45).

Pendidikan antikorupsi sebagai wadah untuk membentuk mental atau karakter antikorupsi, sejalan dengan tujuan pendidikan karakter yaitu membentuk warga negara yang berkarakter. Kesinambungan tujuan ini dapat dipadukan dalam proses pembelajaran di sekolah untuk mengatasi permasalahan-permasalahan moral. Pengembangan pendidikan antikorupsi di sekolah bukan berarti tidak menimbulkan permasalahan baru. 
Permasalahan yang muncul dalam mewujudkan pendidikan antikorupsi di sekolah adalah cara yang digunakan untuk mewujudkannya. Berangkat dari itulah peneliti akan membuat strategi pendidikan antikorupsi berdasarkan hasil observasi dan wawancara agar strategi yang dihasilkan sinergi dengan tradisi sekolah.

Sejalan dengan strategi pengembangan pendidikan karakter, pendidikan antikorupsi disisipkan atau diintegrasikan pada mata pelajaran. Pendidikan antikorupsi dimasukkan dalam kurikulum sekolah. Pendidikan antikorupsi diinterasikan dalam mata pelajaran yang ada.

Pendidikan antikorupsi secara continoum minimal belum cukup sehingga perlu dikembangkan pada continoum maksimal dengan dukungan budaya sekolah terutama dalam konteks penanaman nilai dan pembentukan karakter antikorupsi peserta didik agar memiliki sikap dan perilaku antikorupsi, budaya sekolah disebut juga dengan civic culture. Budaya sekolah dapat dikembangkan melalui kegiatan intrakulikuler dan ekstrakulikuler dengan melibatkan semua warga sekolah.

Pengembangan budaya sekolah serta pembentukan karakter peserta didik akan lebih mudah dilakukan mulai dari jenjang pendidikan dasar, hal ini karena penanaman karakter pada siswa sekolah dasar harus dilakukan secara serius dan berkelanjutan demi mewujudkan generasi muda antikorupsi.Pentingnya penerapan pendidikan antikorupsi ini dilakukan dengan tujuan mengantisipasi adanya pembiasaan-pembiasaan buruk yang dilakukan oleh masyarakat. Hal itu dilihat dari angka korupsi di Indonesia sehingga peneliti ingin mulai menerapkan pendidikan anti korupsi sejak dini untuk mencegah adanya korupsi di masa yang akan datang.

Berdasarkan obsevasi yang dilakukan pada tanggal 09 Januari 2019 yang di lakukan di SDI Sunan Ampel II Sidoarjo menemukan bahwa sekolah tersebut belum menerapkan sepenuhnya penanaman nilai-nilai anti korupsi pada siswa secara langsung. Hal ini terbukti belum adanya pendidikan antikorupsi yang terintegrasi dengan mata pelajaran dan belum ada di lingkungan sekolah seperti ekstrakulikuler. Meskipun sekolah telah berupaya menerapkan kedisiplinan dan menanamkan kejujuran dalam setiap ujian. Penelitian ini jika berhasil akan memberikan memberikan rekomendasi strategi penanaman nilai-nilai antikorupsi mengingat SDI adalah sekolah Islam. Dengan harapan rekomendasi tersebut dapat menjadi model atau rujukan bagi sekolah yang lain.

\section{METODE}

Penelitian ini merupakan jenis penelitian empiris dengan menggunakan pendekatan deskriptif kualitatif. Dalam penelitian ini akan melakukan penggalian langsung pengalaman yang disadari pelakunya dan menggambarkan makna didalamnya. Sasaran yang ingin dicapai dalam penelitian ini adalah mendapatkan informasi serta melihat fakta di lapangan tentang penanaman nilai-nilai antikorupsi di Sekolah Dasar.Fokus penelitian ini adalah penerapan karakter antikorupsi yang ada di sekolah Dasar Islam (SDI) Sunan Ampel II. Data primer dalam penelitian ini diambil dari observasi, dan 
wawancara, sedangkan data sekunder berasal dari dokumentasi.

HASIL

Gambaran Penanaman Nilai-nilai Anti Korupsi di SDI Sunan Ampel II Sidoarjo.

Korupsi ada sejak manusia pertama kali ada di dunia. Kebanyakan orang mendefinisikan kata korupsi menjadi kata yang berarti negatif. Artinya, perbuatan korupsi dapat terjadi karena kasus kekuasaan, birokrasi, ataupun pemerintahan. Perbuatan tersebut menjadikan seseorang untuk memajukan kepentingan golongan dalam suatu sistem pemerintahan. Korupsi juga dapat terjadi karena faktor ekonomi. Sering kali pertengkaran terjadi akibat perbuatan tersebut sehingga hal itu dapat menghilangkan kesejahteraan sosial dilingkungan masyarakat. Pendapat tersebut sejalan dengan yang dikemukakan oleh Harisson (2007:672) bahwa korupsi ada sejak manusia mulai mengenal kelola administrasi. Selain itu korupsi juga dikenal dapat menyalahgunakan agenda politik untuk tujuan tertentu. Sehingga korupsi sering kali di kaitkan dengan pemerintahan. Namun disamping itu dalam kehidupan bangsa juga tak luput dari kata korupsi seperti adanya pemberian hukuman, faktor ekonomi, faktor sosial budaya, kebijakan publik, kebijakan internasional, kesejahteraan nasional, dan pembangunan nasional.

Menurut Undang-undang No. 31 Tahun 1999 (pasal 2 dan 3) juncto undang-undang No. 20 Tahun 2001 menjelaskan bahwa korupsi adalah tidakan melwan hukum atau melakukan perbuatan memperkaya diri sendiri atau orang lain atau suatu korporasi yang dapat merugikan keuangan negara atau perekonomian Negara (Priyono, 2018:30).

Sedangkan menurut Josepph Nye menyatakan bahwa korupsi adalah perbuatan yang menyimpang dari kewajiban formal suatu peran publik karena kepentingan pribadi (personal, keluarga, kelompok terdekat) entah kepentingan itu berupa uang/ status/ pelanggaran aturan yang melarang dilakukannya jenis-jenis tertentu cara memengaruhi yang didasarkan pada kepentingan pribadi (Priyono, 42-43).

Korupsi dapat dilakukan oleh semua pihak baik masyarakat, pemerintah, serta keorganisasian. Banyaknya pengaruh-pengaruh negatif yang dihasilkan dari adanya perbuatan korupsi mengakibatkan banyaknya bentuk pertengkaran. Sehingga perlu adanya upaya pemberantasan korupsi. Di negara Hongkong misalnya, perbuatan korupsi dapat diberantas dengan cara mengorganisasikan semua elemen teori lembaga pemberantasan korupsi. Menurut Kesuma (2009:45) lembaga yang dimaksud yakni sebuah lembaga yang dapat bergerak melalui lembaga pendidikan, lembaga penindakan serta pencegahan. Sehingga pemberantasan korupsi tidak bisa hanya melalui KPK akan tetapi perlunya kesinergisan antar lembaga yang menaunginya, seperti lembaga eksekutif, legislatif, lembaga yudikatif, media, ombudsman, auditor umum, sektor swasta, watchdog, dll. Kesekian banyak lembaga tersebut diharapkan dapat menjalin integrasi sistem untuk memperkuat dalam memberantas korupsi yang sedang terjadi. 
Korupsi merupakan bentuk penyalahgunaan jabatan publik bagi keuntungan pribadi. Sejak akhir dasawarsa 1980-an sikap korupsi erat kaitannya dengan ciri tangan besi, rezim-rezim otoriter yang menempatkan persoalan korupsi sebagai perkara politik. Hal itu dibuktikan ketika jabatan publik telah disalahgunakan untuk mendapatkan keuntungan pribadi ketika pejabat menerima, meminta atau memeras untuk memperoleh suap. Sikap tersebut juga dapat ditemui pada para pekerja swasta aktif menawarkan atau memberikan suap untuk membengkokkan kebijakan dan kinerja otoritas publik demi keuntungan kompetitif dan laba. Jabatan publik juga disalahgunakan bagi keuntungan pribadi bahkan jika suap tidak terjadi, melalui patronasi dan nepotisme, pencurian aset negara, atau pengalihan pendapatan negara.

Perbuatan tersebut disebabkan oleh tingginya gaya hidup masyarakat. Selain itu, banyak kerumitan yang terlibat dalam upaya mengurangi apalagi memberantas korupsi. Pembangkitan kesadaran global serta masuknya agenda antikorupsi dalam bentuk kebijakan, namun belum ada perbaikan secara signifikan. Salah satu langkah yang belum cukup terjadi adalah "menjahit agenda antikorupsi dalam kekhasan situasi negara tertentu". Namun istilah "menjahit dalam kekhasan negara tertentu" itu membawa setiap usaha melawan korupsi memasuki wilayah teka-teki tentang corak politik, ekonomi, budaya, hukum, bahkan agama yang beroprasi dalam kehidupan sehari-hari. Dengan begitu, perlu adanya pola-pola pembiasaan sejak dini pada anak.
Pendidikan merupakan sekumpulan pembelajaran pengetahuan, keterampilan, dan kebiasaan sekelompok orang yang diturunkan dari satu generasi ke generasi berikutnya melalui pengajaran, pelatihan, atau penelitian. Pendidikan sering terjadi di bawah bimbingan orang lain, tetapi juga memungkinkan otodidak. Melalui pendidikan tersebut, pola pembiasaan nilai anti korupsi dapat diterapkan pada siswa. Hal itu menjadi tugas guru dalam memberikan sejumlah pembelajaran yang diintegrasikan dengan nilai-nilai antikorupsi. Selain guru, orang tua juga berperan penting dalam melakukan pembiasaanpembiasaan nilai-nilai antikorupsi. Karena lingkungan juga berperan penting dalam merubah karakter siswa maka perlunya adanya kolaborasi antara guru dan pihak keluarga siswa agar tujuan yang diinginkan tercapai. Dengan begitu, diharapkan siswa mampu memiliki jiwa antikorupsi sejak dini untuk masa depan yang lebih baik.

Sebagaimana yang ditanamkan di SDI Sunan Ampel II Taman Sidoarjo. Di sekolah tersebut setiap harinya selalu terdapat pola pembiasaan yang dilakukan guru melalui pembelajaran yang diintegrasikan lewat pembelajaran dan kegiatan di lingkungan sekolah. Misalnya ketika ada siswa yang terlambat, guru memberikan hukuman yang mendidik pada diri siswa sehingga menimbulkan efek jera pada siswa tersebut untuk tidak mengulanginya lagi. Selain itu banyaknya peristiwa yang mencerminkan niali-nilai antikorupsi. Misalnya seringnya terdapat siswa yang ikut membantu temannya yang sedang kesulitan dalam membeli buku ajarnya, empati siswa untuk 
menjenguk temannya yang sedang sakit, adanya kantin kejujuran, dan lain-lain.

Gambaran-gambaran pola pembiasaan nilai antikorupsi di SDI Sunan Ampel II Taman Sidoarjo tersebut terlihat bagaimana guru membiasakan bersikap pada siswa sehingga siswa ikut mencontoh perbuatan baik guru. Tidak akan terjalin suatu perbuatan baik jika tidak ada panutan pada diri siswa pada guru. Seperti halnya semboyan $\mathrm{Ki}$ Hajar Dewantara dalam yaitu "Ing Ngarsa Sung Tuladha Ing Madya Mangun Karsa Tut Wuri Handayani" yang artinya di depan memberikan teladan, di tengah berbuat keseimbangan dan dibelakang memberi dorongan (Hasbullah, 2015:268) Hasil penelitian dengan mengobservasi dan mewawancacarai informasi kuci serta mendokumentasi temuan di SDI II Sidoarjo, ada sembilan nilai-nilai antikorupsi yang diterapkan di Sekolah tersebut. Temuan sembilan nilai tersebut antara lain meliputi; kedisiplinan, kejujuran, kemandirian, keberanian, keadilan, kesederhanaan, kepedulian, kerja keras, dan tanggungjawab:

\section{Kedisiplinan}

Wibowo (2013:45) menyatakan bahwa kedisiplinan merupakan tindakan yang menunjukkan perilaku tertib dan patuh pada berbagai ketentuan dan peraturan. Manfaat hidup disiplin adalah dapat mencapai tujuan hidup dengan tepat dan efisien. Menurut Wikipedia disiplin merupakan perasaan taat dan patuh terhadap nilai-nilai yang dipercaya merupakan tanggung jawabnya. Pendisiplinan adalah usaha usaha untuk menanamkan nilai ataupun pemaksaan agar subjek memiliki kemampuan untuk menaati sebuah peraturan.Nilai-nilai kedisiplinan telah ditanamamkan kepada siswa-siswa SDI Sidoarjo melalui berbagai aturan yang diterapkan oleh sekolah. Masuk kelas tepat waktu apabila ada siswa yang terlambat masuk kelas maka guru akan meberikan sanksi yang mendidik seperti membaca Alquran agar siswa menjadi disiplin. Sikap disiplin sejatinya adalah sikap antikorupsi. Jika siswa dibiasakan sejak dini mematuhi aturan dan tata tertib atau bersikap disiplin maka akan menjadi kebiasaan. Sikap disiplin tersebut akan dinternalisasi dalam laku sehari-hari sehingga mereka akan menghargai waktu.

Selain masuk kelas tepat waktu, guru juga membiasakan mengumpulkan tugas tepat waktu tanpa toleransi. Bagi yang mengumpulkan tugas terlambat juga akan diberikan sanksi. Upaya guru dalam menegakkan kedisiplinan siswa agar siswa tumbuh berkembang menjadi manusia yang berintegritas. Yaitu menghargai waktu dengan baik dan tidak korupsi waktu. Semangat kedisiplinan akan beriringan dengan semangat antikorupsi yaitu tidak akan mengambil yang bukan haknya, tidak menyeleweng karena menyelewengkan waktu adalah bagian dari korupsi. Perjuangan guru untuk mendisiplinkan siswa perlu sinergi dengan orang tua siswa, seperti yang disampaikan oleh Kepala Sekolah di bawah ini.

"kedisiplinan? Eee, ya ini kaitannya juga dengan orang tua nggeh? Keterlambatan anak berangkat sekolah, keterlambatan anak mungkin juga mengerjakan PR, keterlambatan anak mungkin apa itu menyerahkan tugasnya, iya? Kalau dalam kalau dalam keterlambatan anak 
dengan berangkat sekolah kita juga sama orang tuanya dulu memberitahukan bagaimana tata tertib sekolah yang harus dipenuhi, tapi kalau tetap orang tuanya itu ngantarkan anaknya itu sek terlambat ada hukumannya mbak. Ada hukumannya, tapi hukumannya bukan hukuman fisik ya, tapi yang mendidik karena disini adalah sekolahnya itu dimulai dengan mengaji jadi, jam tujuh seperempat ngaji sampai jam delapan baru ada KBM sekolah jadi keterlambatan anak pada saat ngaji tidak pada saat KBM nggeh, KBM sekolah loh maksudnya tapi KBM ngaji, nah itu juga hukumannya disesuaikan dengan materinya jilid, nah kan disini ikut qiroati mbak"(Wawancara, 2019).

\section{Kejujuran}

Upaya sekolah dalam menanamkan nilai antikorupsi berupa kejujuran dilakukan dengan membentuk koperasi kejujuran sekolah. Dengan adanya koperasi kejujuran sekolah, siswa dilatih agar berperilaku jujur ketika melakukan jual beli berupa atribut sekolah, sehingga dengan adanya koperasi kejujuran, perilaku jujur menjadi kebiasaan (habituasi) siswa dalam kehidupan sehari-hari. Upaya menanamkan kejujuran itu selaras dengan pernyataan ibu Chis selaku kepala sekolah sebagai berikut:

"oo yaa, itu tadii, bisa di dalam kelas. juga bisa di luar kelas nggeh, salah satunya nanti penerapan juga lewat teori, juga praktek entah itu nanti prakteknya itu apa? Ada praktek temannya eee jual beli! Nah, jual beli kan nanti bisa? Entah itu nanti kelas rendah atau kelas tinggi! Nah bagaimana? ee, jual beli yang jujur, tidak ada unsur apa? Nyolong atau tidak ada unsur menipu, mengurangi timbangan atau sebagainya. Nah itu bisa diterapkan seutuhnya, nah ini salah satunya" (Wawancara, 2019).

Setiap siswa dituntut untuk memiliki nilai kejujuran yang tinggi melalui program koperasi kejujuran yang digerakkan oleh pihak sekolah. Pelaksanaan koperasi kejujuran ini tentunya tidak terlepas dari adanya pengawasan yang dilakukan seluruh warga sekolah baik guru maupun staf/karyawan, sehingga mampu mewujudkan sekolah yang memiliki komitmen dalam menanamkan nilai kejujuran pada diri siswa di SD Sunan Ampel II Sidoarjo.

Hal tersebut sejalan dengan pendapat yang dikemukakan oleh Wibowo bahwa kejujuran merupakan perilaku yang didasarkan pada upaya menjadikan dirinya sebagai orang yang selalu dapat dipercaya dalam perkataan, tindakan, dan pekerjaan (Wibowo, 45). Berkaitan dengan nilai kejujuran, dapat dikatakan bahwa SDI Sunan Ampel 2 Sidoarjo sudah menerapkan dan mengajarkan siswa untuk berperilaku jujur dan dapat dipercaya tindakannya dengan adanya kantin kejujuran sekolah.

Selain itu nilai kejujuran juga terlihat ketika seorang siswa mengoreksi hasil pekerjaan yang diberikan guru. Melalui kegiatan ini diharapkan siswa mampu menunjukkan sikap jujur dalam mengoreksi hasil pekerjaannya sendiri. Kegiatan ini merupakan salah satu upaya untuk menanamkan kejujuran pada siswa sejak dini, sehingga siswa memiliki kejujuran melalui pembiasaan yang dilakukan melalui kegiatan tersebut. Hal tersebut terlihat dari wawancara yang dilakukan 
oleh $\mathrm{Bu}$ Mas selaku guru kelas 3A sebagai berikut:

"okey ngeh, gini yah, kalau sikap kejujuran itukan tidak bisa dijadikan lewat kata-kata tapi harus tindakan dan contoh ya? Tindakan dan contoh kebiasaan, pembiasaan sehari hari contohnya waktu koreksi kalau kebiasaan saya ini asli loh ya. Kalo kebiasaan saya tulis dipapan, nah ada satu dua itu jawabannya itu dihapus beda sama di papan nah itu kalau padahal itu sudah saya buatkan......... Jujur harus ditanamkan hayo gaboleh diganti jawabannya, biar salah nilainya jelek gapapa"(Wawancara, 2019).

Mencermati pernyataan Ibu Mas tersebut komitmen SDI untuk menanamkan kejujuran sebagai bagian dari nilai antikorupsi sangat tinggi. Menurutnya kejujuran tidak sebatas ucapan tapi adalah perilaku nyata dalam kehidupan sehari-hari. Dewasa ini kata "jujur" sebatas ucapan yang diagungkan tapi tidak berbanding lurus dengan laku kehidupan sehari-hari. Kontradiksi Inilah yang harus dihindarkan pada siswa sejak dini. Sekaligus menanamkan ucapan selaras dengan perilaku.

\section{Kemandirian}

Nilai kemandirian siswa SDI Sunan Ampel II dapat dilihat melalui 2 cara yaitu mengerjakan tugas secara percaya diri dan melalui ekstrakurikuler renang. Pada ekstrakurikuler renang, sekolah melarang wali murid untuk ikut serta dalam kegiatan tersebut dengan harapan siswa dapat mempersiapkan kebutuhannya sendiri selama kegiatan berlangsung. Wibowo mengatakan bahwa kemandirian merupakan sikap penting yang harus dimiliki seseorang supaya tidak selalu bergantung dengan orang lain. Kemandirian merupakan sikap dan perilaku yang tidak mudah tergantung pada orang lain dalam menyelesaikan tugas (Wibowo, 45). Dengan melaksanakan tugas secara percaya diri, dapat dikatakan bahwa siswa SDI Sunan Ampel II Sidoarjo merupakan siswa yang mandiri dalam belajar. Hal ini didukung oleh pernyataan kepala sekolah sebagai berikut:

"salah satunya. Gaoleh nyontoh, percaya diri sendiri, terus apa-apa tidak ada kecenderungan ketergantungan pada gurunya, njajajan yoo dewe kekamar mandi juga sendiri itu kalau disekolah. Kalau diterapkan dirumah iku yoo, gaoleh sering-sering minta tolong kepada orang tuanya! Berani untuk latihan sendiri walaupun kelas satu!'"Wawancara, 2019).

Hal senada juga diungkapkan oleh bu Khusnul selaku Wakasek kesiswaan, sebagai berikut:

"kemandirian siswa itu, biasanya kita ketika ada renang, sekarang kan kita ada ekstra renang! Orang tua itu sudah tidak boleh ikut!"(Wawancara, 2019).

Temuan penelitian menunjukkan bahwa guru dan pihak sekolah berupaya untuk melakukan pola asuh yang mandiri terhadap siswa di SD Sunan Ampel II Sidoarjo. Sehingga diharapkan pola asuh tersebut dapat mewujudkan dan membiasakan nilai kemandirian pada diri siswa sejak dini baik di lingkungan sekolah 
maupun di lingkungan rumah. Agar nilai kemandirian dapat tertanam pada diri siswa sepenuhnya, maka perlu adanya kerjasama baik antara guru dengan orangtua. Karena pendidikan antikorupsi nilai kemandirian akan berjalan efektif dan berjalan seirama apabila orangtua juga menanamkan kemandirian di lingkungan rumah pula.

\section{Keberanian}

Keberanian siswa dapat ditunjukkan pada saat siswa memimpin do'a di halaman sekolah dan keberanian saat menjawab kuis yang diberikan oleh guru kelasnya. Wibowo (2013:47) menyatakan keberanian merupakan sikap hati yang mantap dan rasa percaya diri yang benar dalam menghadapi kesulitan. Siswa sudah bisa dikatakan memenuhi nilai keberanian ketika siswa tersebut berani memimpin do'a didepan teman-temannya. Selain berani memimpin do'a siswa juga dikatakan berani jika mampu menjawab kuis tanpa mengetahui kebenaran jawaban. Hal tersebut tampak dari cuplikan wawancara yang disampaikan oleh bu Chis selaku kepala sekolah sebagai berikut:

\footnotetext{
"memimpin teman-temannya untuk doa bisa, kan salah satu keberanian yaa dia tampil, memimpin berlatih teman-temannya untuk doa, salah satunya, terus salah satunya memimpin teman-temannya membuka pelajaran, ngaji itu juga bisa, kalau dipelajaran juga, di praktekkan sama gurunya, juga terus ada praktek apa? itukan juga keberanian, apa? jual beli, iku makanan kecil, nahhh, ada apo iku dadi pengusaha kecil-kecilan dan ketika kita ada sesi tanya jawab”. (Wawancara, 2019).
}

Berdasarkan hasil temuan diatas menunjukkan bahwa tindakan seperti meminta siswa untuk memimpin doa dan menjawab kuis merupakan salahsatu upaya atau tindakan yang dilakukan guru untuk menumbuhkan dan memunculkan sikap keberanian pada diri siswa. sekolah sebagai lingkungan kedua setelah lingkungan keluarga dianggap tempat yang efektif untuk membentuk sikap berani pada diri seorang anak, sikap keberanian sangat penting dikuasai. Hal ini karena melalui pengusaan sikap berani siswa akan lebih mampu untuk menunjukkan sikap percaya diri dlam berbagai hal, misalnya mau mengakui kesalahan yang diperbuatnya. Terkait dengan pendidikan anti korupsi, sikap kemberanian sangat dibutuhkan. Karena dengan adanya sikap keberanian akan membangun generasi bangsa yang bermental antikorupsi. Sikap berani mengatakan hal sebenarnya, berani menolak sesuatu yang tidak sesuai dengan aturan, berani mengatakan tidak pada korupsi.

\section{Keadilan}

Nilai keadilan ditunjukkan oleh cara guru memberikan nilai serta hukuman kepada siswa yang melanggar aturan. Wibowo (2013) mengatkan yaitu keadilan merupakan sikap yang menunjukkan tindakan sama berat, tidak berat sebelah, tidak memihak atau pilih kasih, berpihak atau berpegang pada kebenaran, sepatutnya, tidak sewenang-wenang, seimbang, netral, objektif dan proposional. Dapat dikatakan guru sudah menunjukkan nilai keadilan yaitu dengan cara guru memberikan nilai sesuai 
dengan kemampuan siswa serta memberikan hukuman (punishment) sesuai dengan pelanggaran yang dilakukan. Hal tersebut tampak dari hasil wawancara yang dilakukan dengan bu Chis selaku kepala sekolah, sebagai berikut:

"yah keadilan dalam hukuman juga bisa, nggeh? Kalau nilai saya kira kalu nilai itu kan ada ukurane nggeah a? Ada ukurannya, anak bisa seperti ini, seperti ini, ini, ini kan seperti itu? yah bisa juga seh dibilang adil juga bisa, cuman juga dilihat kemampuan anak kalau nilai nggeh? Kemampuan anak juga penting kemampuan anak itu, kan ada yang Iqnya juga tidak sama"(Wawancara, 2019).

Hal senada diungkapkan oleh bu masturoh selaku guru kelas 3A sebagai berikut:

"Hehehe nggeh dari segi memberikan hukuman harus adil meskipun ada anaknya yang mbasio anaknya salah yo tetep dihukum, biasa e kan ooo mentang- mentang anak e bu guru gak dihukum nemennemen, ohh ndak, nngeeh disamakan heheh".(Wawancara, 2019).

Hasil wawancara tersebut menunjukkan bahwa SDI Sunan Ampel II Sidoarjo telah berusaha untuk mananamkan nilai keadilan pada diri siswa melalui berbagai tindakan/upaya yang dilakukan pihak sekolah. Tindakan tersebut terlihat dari upaya guru untuk memberikan hukumanyang sesuai dengan perbuatan atau kesalahan yang dilakukannya. Melalui sikap keadilan ini diharapkan guru dapat membiasakan sikap keadilan pada tiap individu siswa,sehingga dengan membiasakan sikap keadilan di lingkungan sekolah siswa dapat mendapatkan hak yang sama.

\section{Kesederhanaan}

Nilai kesederhanaan dapat dilihat ketika siswa bergaul dengan temannya. Siswa yang memiliki gaya hidup yang tinggi akan menyesuaikan gaya hidup temannya pada saat bermain dan belajar. Wibowo (2012) berpendapat bahwa keserdehanaan merupakan sikap bersahaja, sikap dan perilaku tidak berlebihan, tidak banyak seluk-beluknya, tidak banyak pernik, lugas, apa adanya, hemat, sesuai kebutuhan, dan rendah hati. Sehingga kesederhanaan ini akan muncul ketika siswa mulai beradaptasi dengan temannya, dengan demikian tidak akan terjadi kesenjangan sosial antara teman yang mampu dan kurang mampu. Sikap kesederhanaan tampak dari wawancara yang dilakukan oleh Ibu Chis selaku kepala sekolah, sebagai berikut:

"ehmm rata2 disini itu kan juga dilihat dari segi ekonomi ya mbak itu hee, kesederhanaan itu dilihat dari segi ekonomi, rata2 juga dari ekonomi kebawah yaa"'(Wawancara, 2019).

Hal senada diungkapkan oleh bu Khusnul selaku kesiswaan, sebagai berikut:

"yaa kita dari segi penampilan saja kalau penampilannya terlalu wahh nggeh, akibatnya kan anak-anak looh kok seperti itu? kalau biasanya anak-anak kan nggeh ndak boleh terlalu dari segi pakaiannya, biasanya kan anak-anak yaa pakai perhiasan nggak boleh mbak, akhirnya kan akan terjadi kecenderungan sosial terhadap sesamanya"(Wawancara, 2019) 
Kesederhanaan yang terlihat di SDI Sunan Ampel II Sidoarjo telihat ketika siswa berpenampilan, didalam keseharian siswa tidak diperbolehkan untuk memakai perhiasan yang berlebihan. Larangan ini mengajarkan siswa untuk hidup sederhana, sehingga nantinya diharapkan sikap kesederhanaan ini mampu di internalisasi dalam kehidupan seharihari.

\section{Kepedulian}

Nilai kepedulian siswa dapat dilihat ketika siswa mendapati teman yang sedang kesusahan. Data tersebut sesuai dengan pernyataan Wibowo (2013:45) yang menyatakan bahwa sikap kepedulian merupakan sikap dan tindakan yang selalu ingin memberi bantuan pada orang lain dan masyarakat yang membutuhkan. Sikap kepedulian itu muncul dari diri siswa ketika melihat siswa lain mengalami kesulitan. Sehingga perilaku tersebut murni dihasilkan dari diri siswa itu sendiri tanpa diminta guru. Sikap keadilan yang tercermin di SDI Sunan Ampel 2 Sidoarjo tampak dari wawancara yang dilakukan oleh bu Chis selaku kepala sekolah, sebagai berikut:

"kepedulian kepada teman, nulung koncone lah gampangane ngunu nggeh".....kalau ada temannya yang sakit kita usahakan untuk menjenguknya, seperti itu.....kemudian ada yang sakit umpama sakitnya di sekolah kita suruh temannya untuk mengantarkan sampai kerumah..."1

Temuan penelitian menunjukkan bahwa sikap kepedulian sudah mulai tertanam pada diri siswa di SDI Sunan Ampel II Sidoarjo, hal tersebut terlihat ketika siswa peduli terhadap teman yang mengalami kesusahan. Perilaku tersebut merupakan salahsatu upaya bentuk kepedulian terhadap sesama, selain itu bentuk nilai keadilan dapat terlihat ketika peneliti melakukan observasi di sekolah seperti memindahkan sepeda yang berada area tanaman sekolah. Hal itu menunjukkan bahwa siswa di SDI ini tidak hanya memiliki kepedulian terhadap sesama, akan tetapi memiliki kepedulian terhadap lingkungan sekitarnya. Pembiasaan sikap kepedulian ini diharapkan mampu membentu karakter antikorupsi pada diri siswa dikemudian hari.

\section{Kerja keras}

Nilai kerja keras dapat dilihat ketika siswa bersikap optimis dalam mendapatkan nilai yang bagus dalam ujian sekolah maupun ulangan harian sekolah. data tersebut sesuai dengan pernyataan Wibowo (2013:45) yang menyatakan bahwa kerja keras merupakan perilaku yang menunjukkan upaya sungguh-sungguh dalam mengatasi berbagai hambatan belajar dan tugas, serta menyelesaikan tugas dengan sebaik-baikknya. Sehingga siswa akan berusaha dengan maksimal dalam memperoleh prestasi sekolah, bagaimana ia belajar serta bagaimana ia memperoleh nilai yang diimpikan. Nilai kerja keras yang terlihat di SDI Sunan Ampel II Sidoarjo dapat terlihat pada wawancara pada yang dilakukan pada bu Chis selaku kepala sekolah, sebagai berikut:

${ }^{1}$ Wawancara dengan Kepala Sekolah SDI Sunan Ampel II Sidoarjo. 
"yaa, belajarnya itu dari segi belajarnya terus hasilnya, nah atau PR nya kan itu jadi, yoo mungkin saya kira gurunya juga menanamkan, nek gak nggawe, nek gak nggarap pr juga ada hukumannya, yaa kan berarti bukan berarti mosok bendino dihukum, kan suatu ketika hukuman itu harus diberikan kepada anak". Mungkin peningkatan- peningkatan prestasinya ya? Yaa belajar yaa namanya anak-anak yawes kadang ya ada di beritahu itu ya prestasinya lebih meningkat"(Wawancara, 2019).

Berdasarkan hasil temuan di SDI Sunan Ampel II Sidoarjo menunjukkan bahwa sikap kerja keras terlihat dari ketika siswa bersungguh-sungguh dalam belajar agar mendapatkan nilai atau prestasi dibidang akademik maupun non akademik. Sikap kerja keras yang dimiliki siswa diharapkan mampu membangkitkan semangat dalam belajar. Hasil penelitian memperlihatkan bahwa perilaku kerja keras telah tertanam pada diri siswa, hal itu tentunya tidak terlepas dari peran serta guru dalam membangkitkan semangat belajar siswa di sekolah. Sehingga melalui penanaman sikap kerja keras dalam belajar siswa diharapkan dapat menerapkan sikap tersebut dalam kehidupan sehari-hari.

\section{Tanggung jawab}

Nilai tanggung jawab siswa dapat dilihat ketika siswa tersebut dapat mengumpulkan tugas yang diberikan gurunya dengan tepat waktu. Wibowo (2013:46) menyatakan tanggung jawab merupakan ciri manusia yang beradab (berbudaya). Manusia merasa bertanggung jawab karena ia menyadari akibat baik atau buruk perbuatannya. Kaitannya dengan nilai atau sikap antikorupsi dapat diartikan sebagai kesadaran dalam diri manusia akan tingkah laku serta perbuatan yang disengaja ataupun tidak disengaja menghindari tindak korupsi. Siswa-siswa di SDI Sunan Ampel II Sidoarjo juga diajarkan memiliki rasa tanggung jawab mulai dari hal kecil antara lain tidak membuang sampah sembarangan, piket halaman oleh anak kelas 6 secara bergantian laki-laki dan perempuan. Sehingga dengan begitu sikap tanggung jawab dapat dimiliki seorang siswa dan dapat diterapkan oleh siswa di sekolah, rumah, dan lingkungan sekitar. Hal itu dapat terlihat dari wawancara yang dilakukan pada Ibu Chis selaku kepala sekolah, sebagai berikut:

“...tanggung jawab untuk
mengerjakan PRnya, nggeh? dari
piket yang diberikan, gurunya juga
yang mendisiplinkan anak anak
nggeh, untuk anakanak yang dikelas
begitu bahkan kalau yang kelas
tinggi kelas 6 itu ada tanggung ja-
wab untuk membersihkan halaman,
setiap kali istirahat”. (Wawancara,
2019).

Hasil wawancara di atas menunjukkan bahwa nilai tanggung jawab sudah diterapkan di SDI Sunan Ampel II Sidoarjo, penerapan tersebut terlihat dari beberapa hal kecil antara lain piket sekolah dan tanggung jawab terhadap tugas yang diberikan guru. Upaya terebut diharapkan mampu memunculkan dan membiasakan sikap tanggung jawab pada individu siswa sejak dini, sehingga nantinya sikap ini dapat tertanam hingga dewasa. Nilai tanggung 
jawab sangat penting dikuasai, karena dengan adanya sikap ini mampu mencegah tindakan-tindakan yang memungkinkan merugikan diri sendiri dan orang lain.

Berdasarkan uraian diatas menunjukkan bahwa di SDI Sunan Ampel II Sidoarjo telah berusaha untuk mengimplementasikan kesembilan nilai pendidikan anti korupsi, nilai-nilai tersebut diimplementasikan pihak sekolah dalam proses pembelajaran maupun kegiatan ekstrakurikuler yang memungkinkan nilai-nilai itu dapat diinternalisasi oleh siswa-siswi SDI Sunan Ampel II Sidoarjo. Pentingnya penanaman nilai-nilai antikorupsi sejak dini kepada siswa bertujuan agar tertanam mental antikorupsi, yang nantinya akan menjadi benteng bagi mereka untuk tidak melakukan perbuatan korupsi jika mereka sudah dewasa nanti. Berawal dari lingkungan sekolah, lingkungan keluarga serta lingkungan masyarakat. Oleh karena itu sekolah sebagai lingkungan kedua setelah lingkungan keluarga tentunya memegang peran penting dalam menanamkan dan menumbuhkan sikap antikorupsi sejak dini pada siswa khususnya siswa di SDI Sunan Ampel II Sidoarjo.

\section{SIMPULAN DAN SARAN}

Gambaran penanaman nilai-nilai antikorupsi di SDI Sunan Ampel II Sidoarjo sudah memenuhi 9 nilai-nilai antikorupsi antara lain. Nilai kedisiplinan ditunjukkan dengan siswa datang tepat waktu ke sekolah, nilai kejujuran dilihat dari adanya kantin kejujuran yang ada disekolah, nilai kemandirian dapat dilihat melalui 2 cara yaitu mengerjakan tugas secara percaya diri dan melalui ekstrakurikuler renang, nilai keberanian siswa dapat ditunjukkan pada saat siswa memimpin do'a di halaman sekolah dan keberanian saat menjawab kuis yang diberikan oleh guru kelasnya, nilai keadilan ditunjukkan oleh cara guru memberikan nilai serta hukuman kepada siswa yang melanggar aturan, nilai kesederhanaan dapat dilihat ketika siswa bergaul dengan temannya, nilai kepedulian siswa dapat dilihat ketika siswa mendapati teman yang sedang kesusahan, nilai kerja keras dapat dilihat ketika siswa bersikap optimis dalam mendapatkan nilai yang bagus dalam ujian sekolah maupun ulangan harian sekolah serta nilai tanggung jawab siswa dapat dilihat ketika siswa tersebut dapat mengumpulkan tugas yang diberikan gurunya dengan tepat waktu.

\section{DAFTAR RUJUKAN}

Chis. Wawancara dengan Kepala Sekolah SDI Sunan Ampel II Sidoarjo, 2019.

Gebeye, Berihun. "Corruption and Human Rights: Exploring the Relationships." SSRN Electronic Journal, June 4, 2012. https://doi.org/10.2139/ssrn.207576 6.

Gurning, Nuriani Laura Malau. "Implementasi Pendidikan Antikorupsi Melalui Warung Kejujuran Di Smp Keluarga Kudus." Thesis, UNS (Sebelas Maret University), 2013. https://digilib.uns.ac.id/dokumen/34461/Implementasi-Pendidikan-Antikorupsi-Melalui-WarungKejujuran-Di-Smp-Keluarga-Kudus. Harrison, Elizabeth. "Corruption." Development in Practice 17, no. 4-5 (August 1, 2007): 672-78. https://doi.org/10.1080/0961452070 1469971. 
Hasbullah. Dasar-Dasar Ilmu Pendidikan. Jakarta: Rajawali Press, 2015.

Kesuma, D. Pendidikan Karakter Kajian Teori Dan Praktik Di Sekolah. Bandung: Remaja Rodakarya, 2009.

Khusnul. Wawancara dengan Wakil Kepala Sekolah bidang kesiswaan SDI Sunan Ampel II Sidoarjo, Mei 2019.

Manion, Melanie. "Lessons for Mainland China from Anti-Corruption Reform in Hong Kong," July 11, 2019.

Mas. Wawancara dengan guru Sekolah SDI Sunan Ampel II Sidoarjo kelas 3A, 2019.

Masturoh. Wawancara dengan guru Sekolah SDI Sunan Ampel II Sidoarjo kelas 3A, Mei 2019.

"Not as Easy as It Sounds? Delivering the National Integrity System Approach in Practice The Case Study of the National Anti-Corruption Programme in Lithuania. | Public Administration Quarterly." Accessed July 2019. https://paq.spaef.org/article/744/Not-as-Easy-as-It-SoundsDelivering-the-National-IntegritySystem-Approach-in-Practice-TheCase-Study-of-the-National-AntiCorruption-Programme-in-Lithuania-.

Priyono, B. Herry. Korupsi: melacak arti, menyimak implikasi, 2018.

Sujono. Kejahatan Dan Penegakan Hukum di Indonesia. Yogyakarta: Liberty, 1987.

UU No. 31 Tahun 1999 tentang Pemberantasan Tindak Pidana Korupsi [JDIH BPK RI] (1999). https://peraturan.bpk.go.id/Home/Details/45350/uu-no-31-tahun-1999.

"UU No. 31 Tahun 1999 Tentang Pemberantasan Tindak Pidana Korupsi [JDIH BPK RI]." Accessed July 12, $2019 . \quad$ tps://peraturan.bpk.go.id/Home/Details/45350/uu-no-31-tahun-1999.
UU Nomor 20 Tahun 2001 tentang Pemberantasan Tindak Pidana Korupsi JDIH BSSN (2001). https://jdih.bssn.go.id/arsiphukum/uu-nomor-20-tahun-2001tentang-pemberantasan-tindak-pidana-korupsi.

Wibowo, Agus. Pendidikan Anti Korupsi Di Sekolah: Strategi Internalisasi Pendidikan Anti Korupsi Di Sekolah. Yogyakarta: Pustaka Pelajar, 2013. . Pendidikan Karakter Di Perguruan Tinggi. Yogyakarta: Pustaka Pelajar, 2013.

- Pendidikan Karakter Strategi Membangun Karakter Bangsa Berperadaban. Yogyakarta: Pustaka Pelajar, 2012. 
